Accesed on: http://jkb.ub.ac.id/index.php/jkb/article/view/2970

Jurnal Kedokteran Brawijaya Vol. 31, No. 4, August 2021, pp. 236-241

Article History: Received 3 May 2021, Accepted 14 July 2021

$\underline{\text { Research Article }}$

\title{
Predictive measure for Ischemic Heart Disease among Workers in Jakarta, Indonesia
}

\section{Skor Prediktif pada Penyakit Jantung Iskemik pada Pekerja di Jakarta, Indonesia}

\author{
Leli Hesti I', Gea Pandhita $S^{2}$, Nurhayati Anis ${ }^{3}$, Anna Suraya $^{4}$ \\ ${ }^{1}$ Department of Occupational Health Faculty of Medicine Universitas Muhammadiyah Prof. Dr. Hamka Jakarta \\ ${ }^{2}$ Department of Neurology Faculty of Medicine Universitas Muhammadiyah Prof. Dr. Hamka Jakarta \\ ${ }^{3}$ Department of Public Health Faculty of Medicine Universitas Muhammadiyah Prof. Dr. Hamka Jakarta \\ ${ }^{4}$ Department of Occupational Health and Safety Faculty of Medicine Universitas Binawan Jakarta
}

\begin{abstract}
Ischemic Heart Disease (IHD) is one of the leading causes of morbidity and mortality in many countries, including Indonesia. Therefore, cardiovascular risk-prediction models are required in clinical practice for early detection in high-risk populations, including the worker population. This study intends to develop a predictive risk measure for early detection of IHD incidences among employees in Jakarta, Indonesia. Source of data was the database of 4,100 medical check-up (MCU) results of employees and entrepreneurs in Jakarta and surrounding areas in January to October 2019. Multivariate analysis showed that being aged $>40$ years ( $p=0.000$; OR=5.329 (95\% Cl 2.621-10.833)), having a history of dyspnea ( $p=0.000$; OR=5.699 (95\% Cl 2.524-12.871)), smoking ( $p=0.048$; OR=2.007 (95\% Cl 1.924-4.359)) and $\mathrm{HDL}<50 \mathrm{mg} / \mathrm{dL}(p=0.049$; $O R=1.811$ (95\% Cl 1.099-3.281)) were all good predictors to detect IHD in the worker population. The combination of these predictors results with a cut-off point of 2.5 , showed accuracy $(79.2 \%$ sensitivity and $66.3 \%$ specificity). Workers who have a score $>2.5$ are at high risk of developing IHD in the future. This scoring system can be used by workers or companies to take early preventive measures.
\end{abstract}

Keywords: Ischemic heart disease, predictive risk score, smoking, workers

\begin{abstract}
ABSTRAK
Penyakit Jantung Iskemik (PJI) merupakan salah satu penyebab utama morbiditas dan mortalitas di banyak negara, termasuk Indonesia. Oleh karena itu, model prediksi risiko kardiovaskular diperlukan dalam praktik klinis untuk mengidentifikasi dan mencegah penyakit pada populasi berisiko tinggi, termasuk populasi pekerja. Penelitian ini bertujuan untuk mengembangkan matriks risiko prediktif untuk deteksi dini kejadian Penyakit Jantung Iskemik pada karyawan di Jakarta, Indonesia. Sumber data yang digunakan adalah database 4.100 hasil medical check up (MCU) karyawan di Jakarta dan sekitarnya antara kurang lebih Januari hingga Oktober 2019. Dilakuka analisis pada beberapa faktor risiko untuk mengembangkan sistem penilaian yang dapat digunakan sebagai metode deteksi dini dalam menggambarkan risiko penyakit jantung iskemik pada penduduk yang bekerja di Jakarta, Indonesia. Analisis multivariat menunjukkan usia $>40$ tahun $(p=0.000 ; O R=5.329(95 \% \mathrm{Cl} 2.621-10.833))$, memiliki riwayat dispnea $(p=0.000 ; O R=5.699$ (95\% Cl 2.524-12.871)), merokok ( $p=0,048$; OR=2,007 (95\% Cl 1,924-4,359)) dan HDL <50 mg/dL ( $p=0,049 ;$ OR = 1,811 $(95 \% \mathrm{Cl} 1,099-3,281))$ adalah prediktor yang baik untuk deteksi dini PJI pada populasi pekerja. Kombinasi indikator dengan titik potong 2,5, menunjukkan nilai akurasi prediktif sebesar 79,2\% (sensitivitas) dan 66,3\% (spesifisitas). Pekerja yang memiliki skor $>2,5$ berisiko tinggi mengalami PJI di masa mendatang. Sistem penilaian ini dapat diterapkan oleh pekerja atau perusahaan untuk mengambil tindakan pencegahan dini.
\end{abstract}

Kata Kunci: Merokok, penyakit jantung iskemik, pekerja, skor risiko prediktif

Correspondence: Leli Hesti I. Department of Occupational Health Faculty of Medicine Universitas Muhammadiyah Prof. Dr. Hamka, Jl. Limau II, RT.3/RW.3, Kramat Pela, Kec.Kby. Baru, Kota Jakarta Selatan Tel.0817761064 Email: lelihesti_indriyati@uhamka.ac.id 


\section{INTRODUCTION}

Ischemic heart disease (IHD), a cardiovascular disease (CVD), is responsible for the leading causes of morbidity and mortality in many countries. In Indonesia, CVD is accountable for one-third of all deaths (1). This figure is made more worrying by the fact that heart disease not only affects the elderly but also has been found among younger age groups (2). The younger population plays a crucial role as the productive age group among the working population. Based on data from Statistics Indonesia, as of February 2018, the total number of workers in Indonesia was 133.94 million (3).

This trend in the development of non-communicable diseases has caused changes in the burden of disease in Indonesia. Inpatient claims to the Healthcare and Social Security Agency (BPJS) from January - June 2014 reached 735 thousand cases, absorbing Rp 4.2 trillion in funds (4). This has also occurred in several developed countries. Data from the United States show that one American dies of IHD every 60 seconds, costing the US approximately $\$ 200$ billion each year. The total cost not only stems from hospitalizations and treatment, but also includes loss of productivity (5).

According to Ministerial Regulation No. 02/1980, each company in Indonesia must conduct medical check-ups (MCUs) to assess the effects of specific jobs on their employees' health (6). This activity is also a manifestation of the implementation of occupational health and safety (OHS) programs in order that the company's employees maintain their productivity. From the results of the MCUs, several diseases are able to be detected early in workers, including IHD, which occurs due to several risk factors. Some of these risk factors are modifiable, for instance smoking, hypertension, elevated total cholesterol, excess body weight, and diabetes (7). Together with the potential hazards found in many work environments, including physical, chemical, and psychological hazards, these risk factors may increase the risk of IHD in the working population (8).

Based on the medical check-up (MCU) data from one company in Jakarta using the Jakarta Cardiovascular Score, $38 \%$ of employees were at high risk of developing heart disease (9). Detecting IHD in a large number of workers will undoubtedly be detrimental for many parties, including the government, which must bear the burden of costs for the treatment of diseases. Yet, unfortunately, in Indonesia, the availability of data from MCUs conducted by various companies for research purposes is still limited, even though this data could be used for research on numerous diseases, including occupational diseases. The OHS program in Indonesia is currently still dominated by a safety program to prevent work accidents. In the meantime, occupational health and safety efforts to prevent and control occupational diseases have not been widely implemented. Almost all OHS data is in the form of work accident data, while data on occupational diseases remains extremely minimal (10).

Due to the high prevalence of CVD with its increased cost burden, high-risk workers with various workplace hazards, and the presence of MCU data, it should be possible to outline the relationship between workers' characteristics in Indonesia and the risk of IHD. This study intends to develop a predictive score from several risk factors to act as a tool for detecting IHD among Indonesian workers. This will result in the more optimal utilization of MCU reports. The prevention of diseases should be carried out as early as possible in order to maintain workers' productivity and to ensure that the OHS program is well implemented.

\section{METHOD}

\section{Research Subjects}

This is a diagnostic study using a cross-sectional research design with consecutive sampling by taking data from 4,100 workers from Jakarta and surrounding areas who conducted medical check-ups (MCU) at a clinic providing MCU services to workers from January to October 2019. The subjects of our research were workers aged $>18$ years, who were able to read and write, and who were registered for MCUs. Meanwhile, those who did not attend the MCUs due to certain conditions or whose MCU results were incomplete were excluded.

\section{Variables}

This study's dependent variable is IHD, which was indicated by the results of ECG readings conducted by a cardiologist (Sp.JP) in the form of possible/suspected myocardial infarction or myocardial ischemia, or old myocardial infarction or myocardial ischemia. Demographic parameters, including age, gender, height, weight, and waist circumference, were recorded for all subjects. Body mass index (BMI) is a subject's weight in kilograms divided by their height in meters squared. We used WHO classifications for body mass index and waist circumference (11). Hypertension was defined as systolic blood pressure (sBP) $>140 \mathrm{mmHg}$ and/or diastolic blood pressure $(\mathrm{dBP})>90 \mathrm{mmHg}$ and/or reported use of antihypertensive drugs (12). The cut-off point for the lipid profile, according to NCEPATP III criteria, was determined from the results of the parameters of total cholesterol $<200 \mathrm{mg} / \mathrm{dL}$, LDL $<100 \mathrm{mg} / \mathrm{dL}$, and triglycerides $<150$ $\mathrm{mg} / \mathrm{dL}$, and the cut-off point for HDL cholesterol level $<50$ $\mathrm{mg} / \mathrm{dL}$ and blood glucose level $>200 \mathrm{mg} / \mathrm{dL}$ were taken from PERKENI (the Indonesian Association of Endocrinology) $(13,14)$. History of hypertension, history of chest pain, and dyspnea history came from the answers to a questionnaire provided to the subjects. Smoking was determined from the questionnaire about smoking habits, and included subjects who had continued consuming cigarettes until the day of the MCU without considering length of consumption or number of cigarettes per day. The subjects' exercise levels were defined from the questionnaire answers about routine exercise habits without considering exercise frequency per week.

\section{Statistical Analysis}

Statistical comparisons were performed using the Chisquare test to compare demographics, clinical factors, and the workers' medical history, which are independently associated with ischemic heart disease. Any variables with $p<0.25$ were then included in the multivariate analysis. Multivariate analysis using a logistic regression model was completed to estimate the independent association between predictor variables and the diagnosis of IHD. A two-tailed $p$-value $<0.05$ was considered to be statistically significant. To determine the Area Under the Curve (AUC), 
the Receiver Operating Characteristic (ROC) procedure was then applied and the optimal cut-point value defined to assess the probability of IHD. This stage produced the probability value of IHD in the working population. A sensitivity and specificity test was conducted to analyze the predictive score's validity. Analyses were performed using IBM SPSS Statistics for Windows, Version 27.0.

\section{RESULTS}

The baseline characteristics and results for the ischemic heart disease assessment are shown in Table 1.The majority of the research subjects were men $(83.5 \%)$ and $66.7 \%$ were over 40 years old. Of the 4,100 research subjects, 48 had IHD (1.17\%).

Table 1. Characteristics of the study participants

\begin{tabular}{|c|c|c|}
\hline Variables & $\begin{array}{c}\text { Frequency } \\
N=4100\end{array}$ & $\begin{array}{c}\text { Percentage } \\
(\%)\end{array}$ \\
\hline \multicolumn{3}{|l|}{ Demography } \\
\hline \multicolumn{3}{|l|}{ Gender } \\
\hline Female & 673 & 16.5 \\
\hline Male & 3427 & 83.5 \\
\hline \multicolumn{3}{|l|}{ Age } \\
\hline$\leq 40$ years & 1365 & 33.3 \\
\hline$>40$ years & 2735 & 66.7 \\
\hline \multicolumn{3}{|l|}{ BMI } \\
\hline$\leq 25$ & 2115 & 51.6 \\
\hline$>25$ & 1985 & 48.4 \\
\hline \multicolumn{3}{|c|}{ Waist Circumference } \\
\hline$\leq 80 \mathrm{~cm}$ & 1034 & 25.2 \\
\hline$>80 \mathrm{~cm}$ & 3066 & 74.8 \\
\hline \multicolumn{3}{|l|}{ Lab Results } \\
\hline \multicolumn{3}{|l|}{ Total Cholesterol } \\
\hline$\leq 200 \mathrm{mg} / \mathrm{dL}$ & 2487 & 60.6 \\
\hline$>200 \mathrm{mg} / \mathrm{dL}$ & 1613 & 39.4 \\
\hline \multicolumn{3}{|l|}{ Triglycerides } \\
\hline$\leq 150 \mathrm{mg} / \mathrm{dL}$ & 2974 & 72.5 \\
\hline$>150 \mathrm{mg} / \mathrm{dL}$ & 1126 & 27.5 \\
\hline \multicolumn{3}{|l|}{ HDL } \\
\hline$\geq 50 \mathrm{mg} / \mathrm{dL}$ & 1462 & 35.6 \\
\hline$<50 \mathrm{mg} / \mathrm{dL}$ & 2638 & 64.4 \\
\hline \multicolumn{3}{|l|}{ LDL } \\
\hline$\leq 100 \mathrm{mg} / \mathrm{dL}$ & 713 & 17.4 \\
\hline$>100 \mathrm{mg} / \mathrm{dL}$ & 3387 & 82.6 \\
\hline \multicolumn{3}{|c|}{ Blood Glucose Level } \\
\hline$\leq 200 \mathrm{mg} / \mathrm{dL}$ & 4019 & 98.0 \\
\hline$>200 \mathrm{mg} / \mathrm{dL}$ & 81 & 2.0 \\
\hline \multicolumn{3}{|l|}{ Medical History } \\
\hline \multicolumn{3}{|l|}{ Hypertension } \\
\hline$\leq 140 / 90 \mathrm{mmHg}$ & 3687 & 89.9 \\
\hline$>140 / 90 \mathrm{mmHg}$ & 413 & 10.1 \\
\hline \multicolumn{3}{|c|}{ Hypertension History } \\
\hline No & 4038 & 98.5 \\
\hline Yes & 62 & 1.5 \\
\hline \multicolumn{3}{|c|}{ Chest pain History } \\
\hline No & 4027 & 98.2 \\
\hline Yes & 73 & 1.8 \\
\hline \multicolumn{3}{|l|}{ Dyspnea History } \\
\hline No & 3909 & 95.3 \\
\hline Yes & 191 & 4.7 \\
\hline \multicolumn{3}{|l|}{ Habitual History } \\
\hline \multicolumn{3}{|l|}{ Smoking } \\
\hline No & 2782 & 67.8 \\
\hline Yes & 1318 & 32.2 \\
\hline \multicolumn{3}{|l|}{ Exercise } \\
\hline Regular & 2282 & 55.6 \\
\hline Non-regular & 1818 & 44.4 \\
\hline
\end{tabular}

Note: Table 2 show that there is a significance difference between age, BMI, waist circumference, blood glucose level, dyspnea history and smoking with Ischemic Heart Disease.
Table 2. Brief assessment results of the participants with Ischemic Heart Disease (IHD)

\begin{tabular}{|c|c|c|c|c|c|c|c|}
\hline \multirow[t]{3}{*}{ Variables } & \multicolumn{4}{|c|}{ Ischemic Heart Disease } & \multirow{2}{*}{\multicolumn{2}{|c|}{ Total }} & \multirow[t]{2}{*}{$P$ value } \\
\hline & \multicolumn{2}{|c|}{ No } & \multicolumn{2}{|c|}{ Yes } & & & \\
\hline & $\mathbf{N}$ & $\%$ & $\mathbf{N}$ & $\%$ & $\mathbf{N}$ & $\%$ & \\
\hline \multicolumn{8}{|l|}{ Demography } \\
\hline \multicolumn{8}{|l|}{ Gender } \\
\hline Female & 663 & 98.5 & 10 & 1.5 & 673 & 100.0 & 0.406 \\
\hline Male & 3389 & 98.9 & 38 & 1.1 & 3427 & 100.0 & \\
\hline & & & & & & & Age \\
\hline$\leq 40$ years & 2724 & 99.6 & 11 & 0.4 & 2735 & 100.0 & 0.000 \\
\hline$>40$ years & 1328 & 97.3 & 37 & 2.7 & 1365 & 100.0 & \\
\hline & & & & & & & BMI \\
\hline$<25$ & 2099 & 99.2 & 16 & 0.8 & 2115 & 100.0 & 0.011 \\
\hline$>25$ & 1953 & 99.2 & 32 & 1.6 & 1985 & 100.0 & \\
\hline \multicolumn{8}{|c|}{ Waist Circumference } \\
\hline$<80 \mathrm{~cm}$ & 1028 & 99.4 & 6 & 0.6 & 1034 & 100.0 & 0.041 \\
\hline$>80 \mathrm{~cm}$ & 3024 & 98.6 & 42 & 1.4 & 3066 & 100.0 & \\
\hline \multicolumn{8}{|l|}{ Lab Results } \\
\hline \multicolumn{8}{|c|}{ Total Cholesterol } \\
\hline$<200 \mathrm{mg} \mathrm{dL}$ & 2461 & 99.0 & 26 & 1.0 & 2487 & 100.0 & 0.354 \\
\hline$>200 \mathrm{mg} \mathrm{dL}$ & 1591 & 98.6 & 22 & 1.4 & 1613 & 100.0 & \\
\hline \multicolumn{8}{|l|}{ Triglycerides } \\
\hline$\leq 150 \mathrm{mg} / \mathrm{dL}$ & 2942 & 98.9 & 32 & 1.1 & 2974 & 100.0 & 0.359 \\
\hline$>150 \mathrm{mg} / \mathrm{dL}$ & 1110 & 98.6 & 16 & 1.4 & 1126 & 100.0 & \\
\hline \multicolumn{8}{|l|}{ HDL } \\
\hline$\geq 50 \mathrm{mg} / \mathrm{dL}$ & 1439 & 98.4 & 23 & 1.6 & 1462 & 100.0 & 0.075 \\
\hline$<50 \mathrm{mg} / \mathrm{dL}$ & 2613 & 99.1 & 25 & 0.9 & 2638 & 100.0 & \\
\hline \multicolumn{8}{|l|}{ LDL } \\
\hline$\leq 100 \mathrm{mg} / \mathrm{dL}$ & 704 & 98.7 & 9 & 1.3 & 713 & 100.0 & 0.803 \\
\hline$>100 \mathrm{mg} / \mathrm{dL}$ & 3348 & 98.8 & 39 & 1.2 & 3387 & 100.0 & \\
\hline \multicolumn{8}{|c|}{ Blood Glucose Level } \\
\hline$\leq 200 \mathrm{mg} / \mathrm{dL}$ & 3974 & 98.9 & 45 & 1.1 & 4019 & 100.0 & 0.032 \\
\hline$>200 \mathrm{mg} / \mathrm{dL}$ & 78 & 96.3 & 3 & 3.7 & 81 & 100.0 & \\
\hline \multicolumn{8}{|l|}{ Medical History } \\
\hline \multicolumn{8}{|l|}{ Hypertension } \\
\hline$\leq 140 / 90 \mathrm{mmHg}$ & 3647 & 98.9 & 40 & 1.1 & 3687 & 100.0 & 0.127 \\
\hline$>140 / 90 \mathrm{mmHg}$ & 405 & 98.1 & 8 & 1.9 & 413 & 100.0 & \\
\hline \multicolumn{8}{|c|}{ Hypertension History } \\
\hline No & 3992 & 98.9 & 46 & 1.1 & 4038 & 100.0 & 0.130 \\
\hline Yes & 60 & 96.8 & 2 & 3.2 & 62 & 100.0 & \\
\hline \multicolumn{8}{|c|}{ Chest Pain History } \\
\hline No & 3980 & 98.8 & 47 & 1.2 & 4027 & 100.0 & 0.873 \\
\hline Yes & 72 & 98.6 & 1 & 1.4 & 73 & 100.0 & \\
\hline Dyspnea History & & & & & & & \\
\hline No & 3874 & 99.1 & 35 & 0.9 & 3909 & 100.0 & 0.000 \\
\hline Yes & 178 & 93.2 & 13 & 6.8 & 191 & 100.0 & \\
\hline $\begin{array}{l}\text { Habitual History } \\
\text { Smoking }\end{array}$ & & & & & & & \\
\hline No & 2742 & 98.6 & 40 & 1.4 & 2782 & 100.0 & 0.021 \\
\hline Yes & 1310 & 99.4 & 8 & 0.6 & 1318 & 100.0 & \\
\hline Exercise & & & & & & & \\
\hline Regular & 2258 & 98.9 & 24 & 1.1 & 2282 & 100.0 & 0.427 \\
\hline Non Regular & 1794 & 98.7 & 24 & 1.3 & 1818 & 100.0 & \\
\hline Total & 4052 & 98.8 & 48 & 1.2 & 4100 & 100.0 & \\
\hline
\end{tabular}

Multivariate analysis showed that age $>40$ years $(p=0.000$; $\mathrm{OR}=5.329$ (95\% Cl 2.621-10.833)), a history of dyspnea $(p=0.000 ; O R=5.699$ (95\% Cl 2.524-12.871)), smoking $(p=0.048 ; O R=2.007(95 \% \mathrm{Cl} 1.924-4.359))$ and $\mathrm{HDL}<50$ $\mathrm{mg} / \mathrm{dL}$ ( $\mathrm{p}=0.049 ; \mathrm{OR}=1.811$ (95\% Cl 1.099-3.281)) were all good predictors to detect IHD in the working population (Table 3).

Table 3. Multivariate logistic regression analysis

\begin{tabular}{llrr}
\hline \multicolumn{1}{c}{ Variable } & OR & P value & \multicolumn{1}{c}{ Cl Interval } \\
\hline Age $>\mathbf{4 0}$ years & 5.329 & $\left.0.000^{*}\right)$ & $2.621-10.833$ \\
HDL $<\mathbf{5 0 ~} \mathbf{~ g / d L}$ & 1.811 & $\left.0.049^{*}\right)$ & $1.099-3.281$ \\
Blood Glucose Level $>\mathbf{2 0 0} \mathbf{~ m g / d L}$ & 0.458 & 0.262 & $0.117-1.794$ \\
Dyspnea history & 5.699 & $\left.0.000^{*}\right)$ & $2.524-12.871$ \\
\hline
\end{tabular}


Table 3. Multivariate logistic regression analysis (Cont.)

\begin{tabular}{llrc}
\hline \multicolumn{1}{c}{ Variable } & OR & P value & \multicolumn{1}{c}{ Cl Interval } \\
\hline Hypertension history & 1.338 & 0.732 & $0.253-7.070$ \\
Smoking & 2.007 & $\left.0.048^{*}\right)$ & $1.924-4.359$ \\
BMI $>\mathbf{2 5}$ & 0.631 & 0.199 & $0.312-1.274$ \\
Waist circumference $>\mathbf{8 0 c m}$ & 0.905 & 0.847 & $0.329-2.491$ \\
Hypertension & 2.056 & 0.133 & $0.804-5.260$ \\
\hline
\end{tabular}

Note: ${ }^{*}$ statistically significant

These variables were then combined to produce a predictive score for early detection of IHD among the working population. The scoring was obtained through statistical calculations using the values of B and SE. The resulting predictive score is shown in Table 4. Receiver Operating Characteristics (ROC) produced an AUC value of 0.726 (95\% Cl 0.655-0.797) (Figure 1). By utilizing the sensitivity and specificity values of the AUC curve, we determined the cut-off point. The predictive scores have a cut-off point of 2.5 with $79.2 \%$ sensitivity and $66.3 \%$ specificity.

Table 4. Predictive scoring

\begin{tabular}{llllrr}
\hline Variable & B & S.E & B/SE & B/SE/ 2.145 & Scoring \\
\hline Age & 1.673 & 0.362 & 4.621 & 2.628 & 3 \\
HDL $<\mathbf{5 0 ~} \mathbf{~ g / d L}$ & 0.594 & 0.303 & 1.980 & 1.126 & 1 \\
Smoking & 0.696 & 0.396 & 1.758 & 1 & 1 \\
Dyspnea History & 1.740 & 0.416 & 4.183 & 2.379 & 2 \\
\hline
\end{tabular}

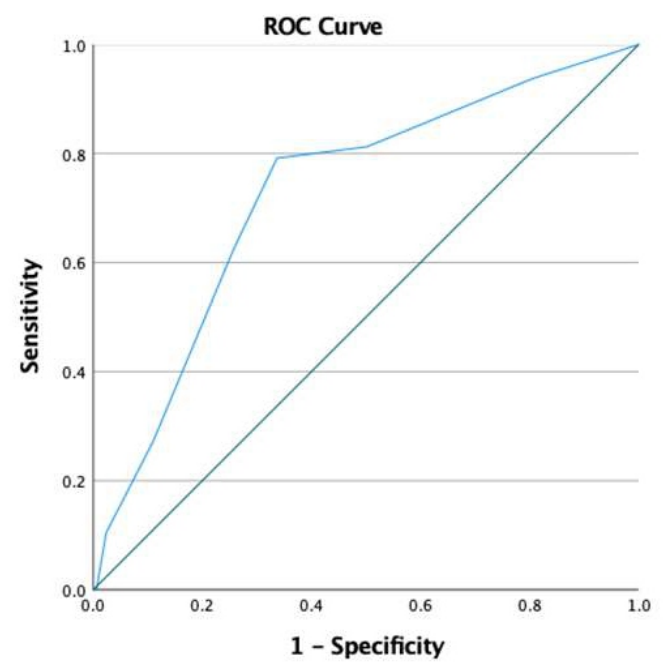

Diagonal segments are produced by ties.

Figure 1. Area Under Curve (AUC) of the predictive score for Ischemic Heart Disease (IHD)

\section{DISCUSSION}

The prevalence of IHD in this study was 48 subjects (1.17\%). The results of the research are similar to a study conducted by the Indonesian Ministry of Health, which found that the national prevalence of coronary heart disease, based on doctor's diagnosis or symptoms, was $1.5 \%$ (15). Therefore, a cardiovascular risk-prediction model is required in clinical practice to identify and prevent the disease in high-risk populations, including the working population.

In this study, we developed a scoring system that can estimate the incidences of IHD, combining several risk factors. The majority (77.1\%) of workers who experienced IHD were aged $>40$ years, with this category being statistically significant with IHD. These results are in line with a study by Ros Endah et al., which showed that an age $>40$ years was associated with IHD (16). In contrast, Fournier et al. and an analysis of INTERHEART data in South Asians showed that myocardial ischemia (MI) was found in younger populations, with incidences of almost $4 \%$ and $11,7 \%$ respectively in the age group $<40$ years $(17,18)$.

These differences may be attributed to the populations' different age distributions, differences in life expectancy, and lifestyles. The elderly have an aging process that correlates with progressive physiological processes, including their effect on the heart and arterial system. Meanwhile, in younger people, smoking was the most critical risk factor for myocardial infarction. Many materials enter the bodies of active and passive smokers, with the potential effect of causing IHD (19).

This fact was identified by Yusuf et al., who suggested that there is an association between smoking and IHD in young people $(\mathrm{OR}=3.33(99 \% \mathrm{Cl} 2.86-3.87))$ which has an odds ratio $(O R)$ higher than older individuals $(O R=2.44(99 \% \mathrm{Cl}$ 2.86-3.87) (20). For this study, smoking status was also one of the risk factors used to build our predictive score. According to a WHO report, in 2018, there were 61.4 million current tobacco users in Indonesia and 147,510 deaths due to CVD caused by smoking (21).

Dyspnea history is one of the parameters of our predictive score, differentiating this score from previous ones. Mario Santos et al. found that dyspnea is associated with a heightened risk of $\mathrm{Ml}$ and heart failure. Mild dyspnea was significantly related with $\mathrm{MI}$ (adjusted Hazard Ratio =1.34; 95\% Cl=1.20-1.50)), along with moderate-to-severe dyspnea with $\mathrm{HR}=1.93,95 \% \mathrm{Cl}=1.41-2.56$ (22). More than half $(52 \%)$ of all workers with IHD in this study recorded $\mathrm{HDL}$ levels $<50 \mathrm{mg} / \mathrm{dL}$, which were associated significantly with the disease. Therefore, this risk factor was included in our predictive score, in line with a cardiovascular study conducted in Quebec and research by Salonen et al., which have confirmed that HDL cholesterol is an independent predictor for IHD $(23,24)$.

The utility of the cardiovascular prediction model has already been proven in evaluating cardiological risk due to multifactorial etiology. Regression formulas have been produced to assess both coronary events and mortality in patients. Probably the most frequently used and oldest model is the Framingham Risk Score (FRS) system. Age, gender, systolic blood pressure, dyslipidemia (total cholesterol and HDL) levels, smoking status, presence of diabetes mellitus (DM), and treatment for hypertension are used as the predictors of this model. In a populationbased study from Southern Europe, the FRS had 51.6\% sensitivity and $85.6 \%$ specificity for women, and $79.1 \%$ sensitivity and $65.9 \%$ specificity for men $(25,26)$. Indonesia itself has developed a cardiovascular riskprediction model, called the Jakarta Cardiovascular Score (SKJ). This model is a modification of the FRS using gender, age, blood pressure, smoking status, diabetes, body mass index, and weekly physical activity as its parameters with $77.9 \%$ sensitivity and $90.0 \%$ specificity (27). Meanwhile, our study proposes a new predictive combination of 4 
parameters consisting of age, smoking status, HDL cholesterol level, and dyspnea history, which has $79.2 \%$ sensitivity and $66.3 \%$ specificity.

To the best of our knowledge, this is the first study to be performed on Indonesia's working population. Several of the equation parameters from the above scoring system were used in this study: age, HDL levels, and smoking status. The history of dyspnea in our score distinguishes this study and makes it unique. Our model has higher sensitivity in women than the SKJ and FRS, but same in men. On the other hand, it has lower specificity in women compared to SKJ and FRS. However, our model is easier to use, with fewer variables, making it more time-efficient. This will undoubtedly help doctors in companies with large numbers of workers. However, we are aware of the

\section{REFERENCES}

1. World Health Organization. NCDs Country Profiles $2018 W H O$. ( O n I i n e ) 2018 . https://www.who.int/nmh/publications/ncdprofiles-2018/en/

2. Gulati R, Behfar A, Narula J, et al. Acute Myocardial Infarction in Young Individuals. Mayo Clinic Proceeding. 2020; 95(1): 136-156.

3. Midayati N. Keadaan Ketenagakerjaan Indonesia Februari 2018. Berita Resmi Statistik. 2018; 42(5): 1-16.

4. Wati H and Thabrany H. Perbandingan Klaim Penyakit Katastropik Peserta Jaminan Kesehatan Nasional di Provinsi DKI Jakarta dan Nusa Tenggara Timur Tahun 2014. Jurnal Ekonomi Kesehatan Indonesia. 2016; 1(2): 18-27.

5. Jayaraj JC, Davatyan K, Subramanian SS, and Priya J. Epidemiology of Myocardial Infarction. Rijeka, Croatia: IntechOpen; 2019: Ch. 2.

6. Menteri Tenaga Kerja dan Transmigrasi Republik Indonesia. Peraturan Menteri Tenaga Kerja dan Transmigrasi No. Per. 02/Men/1980 tentang Pemeriksaan Kesehatan Tenaga Kerja dalam Penyelenggaraan Keselamatan Kerja. Jakarta: Kementerian Tenaga Kerja dan Transmigrasi RI; p. 1-6.

7. Hussain MA, Mamun AA, Peters SAE, Woodward M, and Huxley RR. The Burden of Cardiovascular Disease Attributable to Major Modifiable Risk Factors in Indonesia. Journal of Epidemiology. 2016; 26(10): 515-521.

8. Bortkiewicz A, Gadzicka E, Siedlecka J, et al. WorkRelated Risk Factors of Myocardial Infarction. International Journal of Occupational Medicine and Environmental Health. 2010; 23(3): 255-265.

9. Yusvita F and Nandra NS. Gambaran Tingkat Risiko Penyakit Jantung dan Pembuluh Darah pada Pekerja di PT . X. Forum Ilmiah Jurnal Bunga Rampai. 2018; 15(2): 267-775.

10. International Labour Organization. Profil K3 Nasional Indonesia 2018. Jakarta: ILO; 2019.

11. Han TS and Lean ME. A Clinical Perspective of Obesity, Metabolic Syndrome and Cardiovascular limitations of our study in that the study's population was restricted to the working population and dominated by men. Therefore, validation using a different database consisting of a diverse population with a larger sample size is still required for this formula.

This study proposes a new predictive score with a combination of 4 parameters: age, smoking status, HDL cholesterol levels, and dyspnea history. Workers who have a score $>2.5$ are at high risk of developing IHD in the future. This method is a form of early detection before subjects are referred for a complete examination to establish a diagnosis of IHD. This scoring system can be applied directly by workers or companies to take early preventive measures. In the meantime, a larger multi-center study is required in order that this predictive score can be applied universally.

Disease. JRSM Cardiovascular Disease. 2016; 5: 1-13.

12. Chobanian AV, Bakris GL, Black HR, et al. Seventh report of the Joint National Committee on Prevention, Detection, Evaluation, and Treatment of High Blood Pressure. Hypertension. 2003; 42(6): 1206-1252.

13. Inada A, Weir GC, and Bonner-Weir S. Induced ICER IY Down-Regulates Cyclin A Expression and Cell Proliferation in Insulin-Producing $B$ Cells. Biochemical and Biophysical Research Communications. 2005; 329(3): 925-929.

14. Soelistijo S, Novida H, Rudijanto A, et al. Konsesus Pengelolaan dan Pencegahan Diabetes Melitus Tipe 2 di Indonesia 2015. Jakarta: PB. Perkeni; 2015: p. 82.

15. Ghani L, Susilawati MD, and Novriani H. Faktor Risiko Dominan Penyakit Jantung Koroner di Indonesia. Buletin Penelitian Kesehatatan. 2016; 44(3): 153-164.

16. Patriyani REH and Purwanto DF. Faktor Dominan Risiko Terjadinya Penyakit Jantung Koroner (PJK). Jurnal Keperawatan Global. 2016; 1(1): 23-30.

17. Shah N, Kelly AM, Cox N, Wong C, and Soon K. Myocardial Infarction in the "Young": Risk Factors, Presentation, Management and Prognosis. Heart, Lung \& Circulation. 2016; 25(10): 955-960.

18. Dalal J, Hiremath MS, Das MK, Desai DM, Chopra VK, and Biswas AD. Vascular Disease in Young Indians (20-40 Years): Role of Ischemic Heart Disease. Journal of Clinical and Diagnostic Research. 2016; 10(9): OE08-OE12.

19. Hbejan K. Smoking Effect on Ischemic Heart Disease in Young Patients. Heart Views. 2011; 12(1): 1-6.

20. Yusuf S, Hawken S, Ounpuu S, et al. Erratum: Effect of Potentially Modifiable Risk Factors Associated with Myocardial Infarction in 52 Countries (The INTERHEART Study): Case-Control Study. Lancet. 2004; 364(9438): 937-952.

21. WHO. Heart Disease And Stroke Are The Commonest Ways By Which Tobacco Kills People. (Online) 2018. https://apps.who.int/iris/bitstream/handle/10665/ 272673/wntd_2018_indonesia_fs.pdf

22. Santos M, Kitzman DW, Matsushita K, Loehr L, Sueta CA, and Shah AM. Prognostic Importance of Dyspnea 
for Cardiovascular Outcomes and Mortality in Persons Without Prevalent Cardiopulmonary Disease: The Atherosclerosis Risk in Communities Study. PLoS One. 2016; 11(10): 1-15

23. Després JP, Lemieux I, Dagenais G-R, Cantin B, and Lamarche B. HDL-Cholesterol as a Marker of Coronary Heart Disease Risk: The Quebec Cardiovascular Study. Atherosclerosis. 2000; 153(2): 263-272.

24. Ramirez A and Hu PP. Low High-Density Lipoprotein and Risk of Myocardial Infarction. Clinical Medicine Insights. Cardiology. 2015; 9: 113-117.

25. Artigao-rodenas LM, Carbayo-herencia JA, Divisón- garrote JA, et al. Framingham Risk Score for Prediction of Cardiovascular Diseases: A Population-Based Study from Southern Europe. PLoS One. 2013; 8(9): 1-10.

26. Günaydın ZY, Karagöz A, Bektaş O, et al. Comparison of the Framingham Risk and SCORE Models in Predicting the Presence and Severity of Coronary Artery Disease Considering SYNTAX Score. Anatolian Journal of Cardiology. 2016; 16(6): 412-418.

27. Kusmana D. The Influence of Smoking Cessation, Regular Physical Exercise and/or Physical Activity on Survival: A 13 Years Cohort Study of the Indonesian Population in Jakarta. Medical Journal of Indonesia. 2002; 11(4): 230-242. 